\title{
Growing Up in Technological Worlds: How Modern Technologies Shape the Everyday Lives of Young People
}

\author{
Claus J. Tully \\ German Youth Institute
}

The purpose of this article is to show how young people typically interact with technology. Young people take up modern technology and incorporate it in their everyday lives more rapidly and more unceremoniously than others. As they make use of technical artifacts, the everyday lives of young people change, as does their perception of society, because it is through the artifacts that relationships with others are organized. The significance of technology in young people's everyday lives remains largely unexplored. This deficiency clearly contrasts with an information society, the very basis of which is supposed to be the knowledge of its organizing principles. This article reports on recent findings of how clearly defined social relationships disintegrate because of new technologies and on how young people are challenged to put the applications that technology offers to them into new contexts. The idea is to make a subjectively important choice among the large variety of options given. It shows that technology is no longer result but rather experience oriented. One can foresee the considerable consequences not only for politics, education, and technology development but also for research done in the social sciences.

Keywords: youth technology; old technology; new technology; net generation; images; technology for everyday purposes; communication technology; computer; mobility; automobile; socialization; labor; social differentiation; modernization

M odern technology changes the perceptions that people have of the world and the ways they act within the world. Images and sounds can be stored and manipulated at will. People can participate in faraway events. Accessibility through telecommunications is taken for granted. No matter what we focus on-communication, transportation and access to information, one's own mobility, or the transport of goods-we can see everywhere that technical and social changes are interconnected. In this context, the issue of an original cause is irrelevant: New technologies create new relations and form the basis for innovation. Young people are part of a highly dynamic society. Inevitably, they relate to given technical and social arrangements. No generation before them owned so many artifacts (i.e., tools, gadgets, etc.). Hence, technology strongly influences everyday processes in young people's livesschooling and vocational training, leisure-time organization, club activities or political involvementthey are all dealt with in an entirely different manner by today's young people than they were by the generation of their parents. It is the aim of this article to find out just how young people relate to new technologies, what specific technologies they have at their disposal, and in what contexts they make use of them.

\section{Technology Within Society}

The production of technical gadgets and the use that is made of them accounts for social behavior (see Sombart, 1927/1987). It is no coincidence that we speak of the industrial, the information, or the media society. In the following, we shall distinguish between Technology I and Technology II $^{1}$ to show that traditional technologies, such as machines and assembly lines, and modern technologies, such as computers and the media, belong to different categories. Technology I is determined in spatial, factual, and social terms (i.e., we are dealing with a predictable order of events). 
This is true for bureaucracies as analyzed by Max Weber, for Frederick Winslow Taylor's (so-called scientific) system of management, or for Henry Ford's machine shop. Essentially, Technology I is limited to the world of labor and industry. It is employed whenever specific applications are at issue where each application has its function. However, it is not only the use made of technical systems in certain contexts that is predetermined and therefore standardized but also the organization of social relations around those systems. Thus, the rationality of purpose becomes society's guiding principle. Advanced industrialization and division of labor are characterized by the rational organization of human activities. "The peculiarities of modern culture, and especially its technico-economic foundations, demand the 'calculability' of success" (Weber, 1956, p. 563).

By contrast, Technology II is not clearly determined. It can be found in industry as well as in a person's flat. Its use is not prescribed. Computers, for instance, are multioptional or universal machines of this kind. They can be used to control complex production systems or to write simple texts and check their spelling. The hardware is not designed for specific tasks, and it is, consequently, suitable for nearly any task. This openness requires applications to be matched to specific problems and their solutions. That is, all users of universal machines, such as computers, must work out their very own guidelines for dealing with them. Thus, Technology II contributes to the individualization and destandardization of the institutional environment. Side by side with its use in terms of a rationality of purpose, this technology is valued no less for its aesthetic, emotional, and traditional aspects of application. Physical and mechanical standards for right and wrong applications of technology are discarded in favor of other imperatives, just as, in the field of work organization, new work models are introduced (e.g., job enrichment and group work). To this extent, Technology II can be called a "warm technology" (see McLuhan, 1968) in that because of its meaningful use, social interactions are required; in that the technology is individually available and opens up possibilities for identification; and in that applications are not clearly specified. A new standard for using it can be, for instance, the effect achieved, fulfilling personal or social expectations. Whether this effect was achieved in a rational or irrational way, does not matter. Technology II is more emotion and experience oriented, whereas Technology I is based on rational purposes and is function-oriented.
With respect to recent technical-sociological thinking, we find that other authors make this distinction as well. Bruno Latour describes the relationship between technology and (post)modern society as being "hybrid"(see Latour, 1995) because traditional borderlines between subject and object are beginning to dissolve. A web of blurred relations becomes the framework for people's social interactions. ${ }^{2}$ Technology II, the so-called warm technology, is one of the main producers of hybrids because it urges on the process by which the separation of user and technical artifact disintegrates. Thus, in some situations, we cannot distinguish whether it is people who control their actions or creative computers that compel people to act.

Young people grow up in this artificial world in which the use of technical devices is normal. Gadgets, ${ }^{3}$ such as cell phones, computers, or palms (hand-held computers), structure their lives and affect, for instance, their manner of making appointments, their language, or their aesthetic preferences. Gadgets are indispensable, and their promise to solve problems is greatly trusted. Skeptical attitudes concerning technology become a peripheral matter of the past. The critical distance or reflection that, in the 1970s and 1980s, characterized how young people felt about large-scale technological projects such as nuclear power plants or continental missiles is replaced by a playful approach. Just do it - just try and find out what a technology is good for-becomes the guideline for using technical devices (see Tully, 2000). If it is true that Technology II increasingly determines young people's experiences of the world, then it also contributes to their social integration. Integration, in the sense of a process of personality development between conflicting inner, bioemotional environments and outer, social environments, receives an additional component: It is no longer just family, friends, and mass media that constitute the outer environment but also technical artifacts that establish new relationships, facilitate action, and change modes of perception. For instance, technology can be helpful when a particular lifestyle is to be established and demonstrated, when group affiliations are revealed, and so forth. Technology II is part of an individual's general disposition and therefore of his or her personal socialization. With regard to their technological experiences, young people differ from previous generations. In their comprehensive study, Reinhold Sackmann and Ansgar Weymann (1994) still distinguish between three technology-based generations (prewar, postwar, and envi- 
ronmental). Technology II supports the development of a new generation for which a number of labels already exist (e.g., generation@ and the Internet or computer generation). We might add the gadget generation. In this context, again, it is the everyday use of technical devices and innovations that is important and not spectacular, large-scale technologies. All those little gadgets engender common, generation-specific experiences among today's young people-they are the unifying element. ${ }^{4}$ The current generation of young people, possibly influenced more strongly by technology than by education in the family or by ideals of academic education, creates the basis for what the society of the future will look like. Young people are the next generation to wield power. This requires us to look more closely at their opinions about technology and the use they habitually make of it.

\section{Young People's Interest in Technology}

In the context of an empirical research project conducted by the DJI (German Youth Institute) from 1998 to 2001 and concerned with the lifestyles and mobility needs of young people, we recorded the roles played by communication and other technologies. ${ }^{5}$ Both in the quantitative survey involving 4,500 young people ages 15 to 26 and in the 80 qualitative interviews with individuals, our attention was focused on individual attitudes toward technology.

One set of questions dealt with the interest in technology that had already been examined, at irregular intervals, for several decades. As early as the 1980s, the main thesis, which assumed that young people were considerably hostile toward technology, could not always be confirmed. ${ }^{6}$ According to the Jugend 2000 (Fritzsche, 2000), two thirds of young people said of themselves that they were somewhat or highly interested in technology. There is, however, a consistent gender difference: A distinctive interest in technology is shown predominantly by men: $40 \%$ of men and only $5 \%$ of women admitted to having a strong interest (see Fritzsche, 2000). On average, young people interested in technology name 7.4 fields of activity (of 19 suggested) - photography, environmental protection, and household appliances proving to be a more female domain, whereas male adolescents are more enthusiastic about computers, cars, and multimedia.

In our own survey, we obtained a similar picture. We inquired to what extent the statement, "I'm interested in technology," found approval. About half of all
Table 1. Interest in Technology According to Selected Variables

\begin{tabular}{|c|c|c|}
\hline \multirow[b]{2}{*}{ Variable } & \multicolumn{2}{|c|}{ Interest in Technology } \\
\hline & $\begin{array}{c}\text { Strong } \\
\text { (Technology } \\
\text { Fans) }\end{array}$ & $\begin{array}{c}\text { Slight } \\
\text { (Technology } \\
\text { Grouches) }\end{array}$ \\
\hline Total & 30.6 & 47.2 \\
\hline \multicolumn{3}{|l|}{ Gender } \\
\hline Male & 52.7 & 24.1 \\
\hline Female & 9.3 & 69.5 \\
\hline \multicolumn{3}{|l|}{ Age } \\
\hline 15 to 17 years old & 31.8 & 46.3 \\
\hline 18 to 21 years old & 32.9 & 47.6 \\
\hline 22 to 26 years old & 27.5 & 47.8 \\
\hline \multicolumn{3}{|l|}{ Education } \\
\hline Up to Grade 9 (hauptschule) & 33.7 & 44.9 \\
\hline Up to Grade 10 (realschule) & 35.5 & 45.2 \\
\hline Up to Grade 12 or 13 (gymnasium) & 25.5 & 49.7 \\
\hline \multicolumn{3}{|l|}{ Region } \\
\hline Urban & 28.3 & 48.7 \\
\hline Rural & 33.9 & 45.7 \\
\hline
\end{tabular}

interviewees mentioned a slight interest, barely a third a strong interest (see Table 1), which seemed to depend mainly on gender and regional origin. More than half of young men, but only $9 \%$ of young women, admitted to having a strong interest in technical matters. Interviewees from rural areas showed an affinity for technology somewhat more frequently than city dwellers. The variables of age and of educational level indicated no unilinear effect. There is a tendency for older youths (22-26 years of age) and those having a higher level of education (high school graduation) to disassociate themselves increasingly from technical interests.

As further evaluations show, the attitude toward technology corresponds to other indicators. If one collects those interviewees who show a strong interest in technology in a group of technology fans and those who show slight or no interest in technology in a group of technology grouches, and if one includes other variables of opinion and of behavior, then the interest or lack of interest in technology becomes part of a lifestyle. In this respect, technology serves as a means of self-stylization and symbolization-fans acquire their driver's license a few months earlier than grouches do, they have motorized vehicles at their disposal more often and get less involved in environmental protection, and they play down the influence of cars on pollution (see Table 2 and 3).

Technology fans value cars far more positively and local public transport and walking more negatively.? 
Table 2. A Comparison of Mean Values of Technology Fans With Mean Values of Technology Grouches Regarding Certain Attitudes

\begin{tabular}{|c|c|c|c|}
\hline \multirow[b]{2}{*}{ Attitude } & \multirow[b]{2}{*}{ Total } & \multicolumn{2}{|c|}{ "I am Interested in Technology." } \\
\hline & & $\begin{array}{l}\text { "Quite/Very True" } \\
\text { (Technology Fans) }\end{array}$ & $\begin{array}{l}\text { "Not True" } \\
\text { (Technology Grouches) }\end{array}$ \\
\hline \multicolumn{4}{|l|}{ Positive attitude toward means of transport } \\
\hline Car & 3.6 & 3.7 & 3.5 \\
\hline Local public transport & 2.9 & 2.8 & 3.0 \\
\hline Walking & 2.4 & 2.3 & 2.4 \\
\hline \multicolumn{4}{|l|}{ Environmental protection of means of transportation } \\
\hline Politics and the economy are responsible for environmental protection & 3.2 & 3.3 & 3.2 \\
\hline One is personally responsible for environmental protection & 2.4 & 2.2 & 2.4 \\
\hline $\begin{array}{l}\text { By choosing an appropriate means of transport, one can contribute to } \\
\text { environmental protection }\end{array}$ & 3.4 & 3.3 & 3.5 \\
\hline Cars are responsible for the destruction of the environment & 3.7 & 3.6 & 3.8 \\
\hline \multicolumn{4}{|l|}{ Car characteristics } \\
\hline "Controlling", & 2.6 & 2.9 & 2.4 \\
\hline "Instrumental" & 3.3 & 3.2 & 3.4 \\
\hline$N$ & 4414 & 1340 & 1158 \\
\hline
\end{tabular}

Note: High values indicate strong agreement with the respective variables in the first column. The answer categories ranged from 1 (not at all true) to 5 (entirely true).

Table 3. A Comparison of Technology Fans With the Other Groups Regarding Concrete Behavior

\begin{tabular}{|c|c|c|c|}
\hline & \multirow[b]{2}{*}{ Total } & \multicolumn{2}{|c|}{ "Not True" "I am Interested in Technology." } \\
\hline & & $\begin{array}{l}\text { 'Quite/Very True” } \\
\text { (Technology Fans) }\end{array}$ & $\begin{array}{c}\text { 'Not True" } \\
\text { (Technology Grouches) }\end{array}$ \\
\hline \multicolumn{4}{|l|}{ Action (in percentages) } \\
\hline Ownership of a driver's license & 58.9 & 63.7 & 51.7 \\
\hline Availability of one's own, motorized, individual means of transport & 41.2 & 52.1 & 31.8 \\
\hline Belonging to technology-oriented groups (car and motorbike fans) & 7.0 & 17.5 & 1.2 \\
\hline High expenditures per year for technical items (car or communication) & 9.0 & 14.6 & 5.7 \\
\hline Percentage of trips done per motorized individual means of transport & 41.5 & 46.5 & 37.0 \\
\hline \multicolumn{4}{|l|}{ Action (mean values) } \\
\hline Technology-oriented leisure time activities (e.g., driving) & 2.5 & 2.9 & 2.1 \\
\hline Environmentally friendly behavior & 3.4 & 3.3 & 3.4 \\
\hline Highly mobile days per year (holidays or one-day excursions) & 34.6 & 35.2 & 3.9 \\
\hline \multicolumn{4}{|l|}{ Average number of trips } \\
\hline Workdays & 4.0 & 3.8 & 4.0 \\
\hline Saturdays & 3.1 & 2.9 & 3.2 \\
\hline
\end{tabular}

Note: High values indicate strong agreement with the respective variables in first column. The answer categories for technology-oriented leisure-time activities ranged from 1 (never) to 5 (always). For environmentally friendly behavior (i.e., buying ecofriendly products or garbage sorting) they ranged from 1 (not true at all) to 6 (entirely true).

They delegate responsibility for environmental protection more strongly to higher ranking systems, such as the economy and politics, and refuse to take personal responsibility. They play down the contribution of cars to pollution and more rarely acknowledge the possibility of choosing ecofriendly means of transportation. When they think of buying a car, features such as speed, sportiness, and the latest technology (i.e., controlling features) are just about as important as utility- oriented features such as reliability, ecofriendliness, and safety (i.e., instrumental features). ${ }^{8}$

About two thirds of technology fans (64\%) have a driver's license. ${ }^{9}$ Moreover, they have their own cars, mopeds, and so forth available more frequently. The data show that fans feel a stronger need to drive themselves. Conversely, they are less willing to use transportation. Moreover, they invest more of the money that they have at their disposal in technical equipment 
(e.g., cars or computers) and in driving. Interest in technology also shows in the use they make of their leisure time because they invest not only money but also a lot of time in dealing with technical matters-driving or repairing cars or working with computers is clearly a more frequent preoccupation among technology fans than among technology grouches.

Generally speaking, fans have a more emotional relation to cars and appreciate features of a car like speed or extravagant design more readily. The identification with technology-oriented lifestyles is relevant to the extent that certain persuasive messages (suggesting, for instance, that people should decide to use public transport) are perceived by young people in subtly differentiated ways. Pedagogical measures can be successful only if they do justice to the various realities of young people's lives.

\section{Meanings of Technology}

Via qualitative interview evaluation, it is also possible to portray young people's concrete, interactive experiences with technology. In this regard, it is conspicuous that the presence of technology in very different social situations is experienced as normal or, as a 17-year-old student put it: "If you look around, somehow everybody has a PC. Most people have a cell phone. Technology - that's everyday gadgets, and they're used tremendously" (Anonymous, personal communication, spring 2002). Competence in dealing with technology is taken for granted. "I think that the younger generations, like the 14-to18-year-olds, for them, it's normal. They're casual about using cell phones and the like, but also the vocabulary-all that is changing" (Anonymous, personal communication, spring 2002). Nowadays, technology is no longer limited to experiences in the areas of work or education. Rather, its new quality shows up in the connections that can be made in everyday styles of communication, including occasional moments of irritability. The many different options combined with the so-called colonization of everyday life through technical devices account for a new stage in the process of rendering social conditions more "artificial" (Popitz, 1995).

For example, 18-year-old Johanna refers to these developments in our interviews, speaking of the advantages that new household technologies provide. Repetitive tasks are made easier and carried out faster.
Well, we have a little hand-operated vacuum cleaner which is just super, much easier. If you're cleaning the inside of a car and don't have to carry that big Hoover outside and look for the nearest power outlet. Before, cleaning the car was actually a real pain. . . . Many things are made easier... The time it takes to use a broom, and right after, there's dust everywhere again anyway. Meanwhile, we've got these super throw-away cloths. (Anonymous, personal communication, spring 2002).

Technical devices are becoming smaller, more manageable, and cheaper, and so nearly every household has them. Do-it-yourself is the new rule, undermining traditional job skills and resorting to knowledge that it takes you only a short time to acquire on your own.

Along with these unquestioned and normal developments in the everyday use of technology, young people in our interviews point out five main aspects of technology. Depending on context, technology can take on different meanings or functions for interviewees. Thus, they deal productively with its omnipresence. In the following, the five dimensions will be illustrated with interview excerpts.

\section{Technology as a Building Block for One's Own Future}

Knowledge of technical details concerning computers and the Internet is a resource for jobs with a future. Christoph (age 18) sums up the role of technology as follows: "Yes, I must say that technology is very important for young people because it's the only thing that opens up a perspective on the future. And if you're not interested in technology, you'll probably have a job problem" (Anonymous, personal communication, spring 2002). It is an exception for young people to see the risks in technical developments or to consider them a reason for being pessimistic. Technologies are seen as an opportunity to conquer the world. They are equated with the future and with the power to create it. Matthias gives the following description:

Well, I think [the importance of technology] will increase more and more. I notice that at college. ... Not only in the field of computers and telecommunications but also and especially where jobs are at stake you have to be able to demonstrate basic technical knowledge. (Anonymous, personal communication, spring 2002) 


\section{Technology as Symbolic Capital}

New technologies give prestige and are therefore directly relevant for the perception of third parties. Social acceptance goes hand in hand with the technical artifacts people have at their disposal. Their symbolic significance goes hand in hand with their actual performance parameters when, for instance, the ownership of a cell phone secures integration in the peer group. Sonja (age 17) puts it this way: "Everybody needs a cell phone, actually. ... Precisely when you're 15,16 or so, technology is important." Because of the topics that are talked about in the group, "Yes, I've got a moped, or I'm getting my moped license. . . . It matters a lot what kind of machine you've got or what kind of computer" (Anonymous, personal communication, spring 2002).

In another interview, a girl explains that, thanks to an integrated-services digital-network-connection, she can now call two people at the same time, and if she used her cell phone as well, she could even talk to three people at once. What looks like a meaningless adding up of numbers really proves the outstanding role of technology in the synchronization of young people's everyday lives. The number of phone calls and short messages coming in becomes the indicator for social integration. A girl was reported to spend 6 hours a day on the phone during her holidays, which was interpreted as being an expression of being held in the highest regard by the group.

\section{Technology as a Medium for Experiences}

Frequently, young people simply consider the use of technology to be a lot of fun. Technology is another possibility to try out new things or to find relaxation. With regard to this fun factor, there is no difference between boys and girls. We can gauge this, for instance, from the ownership of cell phones, where girls are boys' equals in every way. Thus, objects that promise convenience, comfort and joy find the highest acceptance during adolescence. These feelings are obviously generated when downloading tone signals for cell phones or the latest music singles for the $C D$ burner. And precisely because there are so many possibilities, a systematic procedure for discovering and for trying out technologies would be beside the point. Their playful use and appropriation is the main thing. Exactly like someone who likes tinkering with things, Andreas (age 18) says, "I don't know, but technology is simply what my life is all about. I'm not attending the technical branch of my high school for nothing. I love looking at Formula-1 cars. It's fascinating, the way they're built" (Anonymous, personal communication, spring 2002).

\section{Technology as an Object of Social Differentiation}

Where the promises and the effects of technology are at issue, judgments are quite different depending on what generation, social stratum, or gender a person belongs to. The access that young people find to technology corresponds to their real-life experiences, and in that respect, they differ from adults. With regard to generational differences, they emphasize again and again that they, the youths, are "probably more open" to the latest technical developments because they are

maybe more curious and eager to learn. Older folks have gotten so used to conventional things - why should they change over now. ... I think young people are more likely to venture into new fields, to learn something new for a change ... not only because it's important for young people but for all of us. We all need it. (Anonymous, personal communication, spring 2002)

Whoever has dealt with technology from childhood on develops skills according to digital requirements, just as 18-year-old Andreas did. Among other things, it was the lack of leisure-time provision in the country that led him to while away his time with computer games.

That's what it's like for some of us, that we really do spend 5, 6 hours at the PlayStation. I think that, from 25, 26 years on, it's like you're still up to date, you still understand what's going on up front, as far as cell phones are concerned. Young people have a better way of living and growing up with these things. (Anonymous, personal communication, spring 2002)

Gender-specific differences in the use of technology can also be determined. This is shown, for instance, in the social constellations of its use, as one young man explains:

It depends on your circle of friends. For example, among girls, computers simply don't matter. I know three girls, maybe, who are really inter- 
ested in computers. Among boys, however, it's different. For me, technology is a question of interest groups and the friends you have. (Anonymous, personal communication, spring 2002)

Certain new technologies however, with cell phones in first place, seem to tally better with female lifestyles because here ownership and use are distributed almost equally between genders. The question of whether technology as a whole was an affair more for men than for women was answered by another female interviewee:

Of course, it also concerns women, that's for sure. It may be true that women don't know their way around car technology as well as men. But women are becoming more independent and can find out what's wrong by themselves. . . In that respect, times have really changed, I think. (Anonymous, personal communication, spring 2002)

\section{Technology as an Agent for Order in Everyday Social Life}

Young people using technologies give structure to their everyday lives. Technologies facilitate and at the same time set limits for social action. Technology is shaping society is the formula used in socioconstructivist technology research. In German-speaking countries, the notion that technology shapes society is not considered to be differentiated enough. Nevertheless, social action changes when everyday life is awash with technology:

I would say that technology is very important for young people aged around 16 to 26 . I'm thinking of the cell phone, in particular, the use of which has increased tremendously in the last 2, 3 years among young people, the way communication takes place, to come to agreements, make appointments, to go for a drive somewhere together. ... For example, if you want to go to a disco or somewhere else on weekends, you no longer fix a time in advance like you used to on the fixed-line network. Attitudes have changed, and young people now say, "We're taking the car" and decide appointments on the cell phone while they're driving. ... If you look at computer games, for instance, even 5- and 6-year-olds are on to them. In the old days, maybe, they played in the sandbox or ran away from home, whereas now they experience the world with Nintendo or computer games, discover a 3-D universe, which they can do no other way. (Anonymous, personal communication, spring 2002)

How do new developments in communications technology affect mobility? Young people rarely make plans for their mobility. What is more important is a high degree of flexibility. It is interesting that a majority of young people, when asked about the effects of communications technologies on mobility as they practice it, reinterpret the question several times and prefer to speak about effects on their way of making appointments. In adolescence, mobility, communication, and appointments seem to be closely related.

I think the way we make appointments is changing. I think that before you actually get together at some specific place, you've got to make 10 phone calls like "Oh yeah, we'll figure that out later," or "By the way, I just want to call so-andso about it, too," or "Oops, I've just seen I can't make it till half an hour later, so why don't you come half an hour later, too." (Anonymous, personal communication, spring 2002)

The everyday lives of young people change when, as described here, technologies are present everywhere. New individual lifestyles and social arrangements develop.

\section{Technology in the Everyday Lives of Young People}

Young people deal with devices of the Technology II type. A brief survey of their everyday lives shows the following technology-related highlights: At the age of 18, nearly everyone has a driver's license (see Tully, 1998). Of the estimated 50 million cell phones in Germany, $30 \%$ to $40 \%$ are in the hands of children and adolescents. Meanwhile, three quarters of 12-to-19year-olds have a cell phone of their own (see JIMStudie, 2002). As for using the Internet, the 20-to-29year-olds take first place. Two out of three young people have already gained experience in the use of the Internet, and 5 out of 10 say they have a PC of their own. Young people from educated families are more strongly interested in this new technology. They own a computer more often and use the Internet more often. On the other hand, young people from less educated 
families are keen on traditional technologies such as cars, motorcycles, machines, or household appliances. In the following, three areas have been selected to demonstrate how the everyday lives of young people are shaped by technology.

\section{Computers, Internet, Cell Phones}

Even 4 years ago, half of the 12-to-19-year-olds gave themselves good marks for knowing how to cope with hardware and software. Today, four out of five young people work with a PC. During the last 4 years, the margin between boys and girls in the use of computers has been halved; meanwhile, $79 \%$ of girls and $87 \%$ of boys state that they use a computer at least once a month in their free time (see JIM-Studie, 1999). Particularly in the age group of 14- and 15-year-olds, female computer users can be found nearly as often as their male counterparts. Moreover, $60 \%$ of children report that they have repeatedly used a PC, and 30\% report that they have repeatedly used the Internet (KIM-Studie, 2001). The increasing importance of digital media corresponds to the decreasing importance of classical print media- a fact that is mirrored in young people's preferences for the Internet. More than $50 \%$ of male and of female Internet users of this generation have been to a radio-station or televisionchannel website or that of a newspaper. So-called chat sites, which are available in schools, for instance, are also very popular. Boys like going to information sites such as sports and (computer) games. Girls and young women prefer sites about stars, VIPs, and their biographies (JIM-Studie, 1999, p. 48). Surfing the Internetas $63 \%$ of young people do-remains a leisure-time activity and a diversion for the time being. But it also serves, although somewhat less, as a means to look up information and to conduct research. However, young people find that sending e-mails, chatting, and downloading music are the more important options that the Internet has to offer.

Cell phones, like the Internet, are a relatively new phenomenon. Even so, they have achieved a youthcultural significance of their own (KIM-Studie, 2001). In 1999 , it was only $14 \%$ of 12 -to-19-year-olds who stated that they owned a cell phone. Today, it is 8 out of 10 young people who state that they have a mobile phone of their own (Deutsche Shell, 2002). Most of the younger interviewees make use of prepaid cards, which give them better control of their expenses. Later on, they choose fixed contracts. Young people spend an average of 23 euros per month on phone calls. The most important activities on the cell phone are sending short messages (about six a day) and making phone calls. Girls use the Short Message Service (SMS) more often than do boys. As for ownership of cell phones, there are no differences between genders. It is interesting to note that most SMS messages are sent from home. Thus, the cell phone becomes an independent medium "because it cannot be checked on by others. As it's easy to guess, parents and relatives are not the preferred communication partners" (Höflich, 2001, p. 12). Along with their function of keeping other generations at arm's length, cell phones are instruments of finding reassurance among friends. Thus, they become a medium that starts the process of separating from the parental home and that facilitates integration into groups of people of the same age. This observation can be extended to other artifacts; cell phones, computers, and the Internet become symbols of youth culture and at the same time contribute to solving the problems of adolescence. What becomes apparent is that the social features of technologies do not coincide with their technical parameters or original purpose. Originally, SMS was developed for business people who wanted to be available even where radio communication was interrupted. Hence, the development of technology cannot be equated with its applications. Innovation is one thing, the social implementation of new technologies another, and in this regard, companies that launch a product in the market and advertise it, as well as customers, interest groups, and political institutions play a major part. Finally, young people's reactions to technical products can hardly be anticipated. The only thing that seems to be sure is that new technology does not always have to promise greater efficiency or rational applications but only multiple options. If a technology can be used in many different ways (e.g., symbolically), then it can possibly be used in the everyday lives of young people as well. Comfort and joy are more important than factual-performance parameters.

\section{Technologies That Serve Mobility}

People's journeys and day trips by any kind of vehicle or by plane are based on technology. Whoever does not want to move around on foot must use technical artifacts. Especially among young people, the car turns out to be a "tandem of technology and individuality," quite in the sense of Technology II (Luhmann, 1992). Our survey has shown that the statuses of technologies facilitating individual mobility grow with 
Table 4. Variables Related to Interest in Technology

\begin{tabular}{|c|c|c|}
\hline Variable & Average $^{a}$ & $\begin{array}{l}\text { Standard } \\
\text { Deviation }\end{array}$ \\
\hline $\begin{array}{l}\text { If you understand technology, } \\
\text { you enjoy driving }\end{array}$ & 2.59 & 1.24 \\
\hline I am interested in technology & 2.69 & 1.36 \\
\hline Cars are utility articles only & 3.42 & 1.26 \\
\hline
\end{tabular}

a. Agreement could be expressed on a scale ranging from 1 (not true) to 5 (entirely true). Thus, the theoretical average for all three items was 3.0.

people's age and maturity. When young people are asked about their vehicle, it is bicycles that, up to the age of 17, are considered by far the most important means of transportation. At the age of 18, they are suddenly replaced by cars because in Germany, a driver's license can be obtained only when you are 18 . The fact that young people become independent early also changes their relation to technologies serving mobility. This is emphasized by the data on driver's-license ownership. At the beginning of the 1980s, the driver's license for cars was obtained at an average age of 19 years and 3 months; today, according to our own calculations, young men obtain it at the age of 18 years and 7 months, women at the age of 18 years and 10 months. Within 2 decades, the age has moved forward by half a year. If this pace continues, legislators will sooner or later have to react by moving forward the age limit, too. In parts of the United States, the age limit is already 16. It is also interesting that drivers' licenses in the country are obtained about 2 months earlier than in the city. Possibly, the greater willingness to deal with technology compensates for a lack of leisure-time options, a pattern that also showed in our qualitative evaluations. ${ }^{10}$

Technologies serving mobility are similar to communications technology in that they promote personal lifestyles. Technology-supported driving and leisuretime behavior shapes a person's identity. For the friends of technology, above all, cars are rarely a mere commodity. They appreciate the so-called show features that simultaneously emphasize their own personalities. Consequently, they find it difficult to switch over from cars to public transport. The reason for this is not always time-saving or constant availability. Rather, what matters when driving is "experience and effect," the enjoyment of technology, color, and engine sound (Tully, 1998). But even those young people who are not explicit friends of technology depend on its mobility-serving variety. The mute force of circum-

\begin{tabular}{lc|cc}
\hline & & \multicolumn{2}{c}{$\begin{array}{c}\text { Item 1: "If you understand } \\
\text { technology, you enjoy driving." }\end{array}$} \\
& & Very True & Not Very True \\
\hline $\begin{array}{l}\text { Item 3: } \\
\text { "Cars are }\end{array}$ & Very True & $\begin{array}{c}\text { Interested } \\
(N=397)\end{array}$ & $\begin{array}{c}\text { Instrumental users } \\
(N=2,680)\end{array}$ \\
$\begin{array}{l}\text { utility } \\
\text { only." }\end{array}$ & $\begin{array}{c}\text { Not Very } \\
\text { True }\end{array}$ & $\begin{array}{c}\text { Controlling users } \\
(N=891)\end{array}$ & $\begin{array}{c}\text { Not interested } \\
(N=406)\end{array}$ \\
\hline
\end{tabular}

Figure 1. Interest in Technology and Car Mobility-Two Types

stances compels people to deal with it, to accept it, and to use it. Young people grow up in a world that appreciates mobility and flexibility, and they do not want to evade those maxims.

\section{Mobility Styles Depend on Interest in Technology}

In our questionnaires, we were able to determine degrees of interest in technology (see Table 4).

In a further step to illustrate our point, we developed two types of technology mobility. Controlling users enjoy driving to the extent that they know something about technical things. Cars are technical objects, and what matters is the impression that you make with them (i.e., symbolic importance). Instrumental users, on the whole, are less interested in technical details and consider cars mainly as utility articles. All the other interviewees were gathered in the mixed categories of interested and not interested ${ }^{11}$ and were neglected in the subsequent parts of our study. ${ }^{12}$

To illustrate the two types, I will refer to material from a group discussion.

Timo (age 19) represents the technology-mobility type of controlling user that was determined by means of a cluster analysis. He explains that he could not "bear to have a car in front of him without overtaking it" (Anonymous, personal communication, spring 2002). He had to "drive himself," otherwise he would get bored. That is why "going by train" was not his style at all. He travels either by car or by plane. For Timo, a holiday starts when he arrives at his holiday resort. Because he likes driving, he chooses destinations in Europe that are quite far away.

Olaf represents the second type, the instrumental user. Olaf owns a car. However, he is ecologi- 


\begin{tabular}{|c|c|c|c|}
\hline & & \multicolumn{2}{|c|}{$\begin{array}{l}\text { Variable 1: "Environmental protection } \\
\text { strongly influences my behavior." }\end{array}$} \\
\hline & & Very True & Not Very True \\
\hline $\begin{array}{l}\text { Variable 2: } \\
\text { "I am }\end{array}$ & Very True & $\begin{array}{l}\text { Those who } \\
\text { delegate } \\
(N=1,041)\end{array}$ & $\begin{array}{l}\text { Interested in } \\
\text { technology } \\
(N=1,263)\end{array}$ \\
\hline $\begin{array}{l}\text { in } \\
\text { technology." }\end{array}$ & $\begin{array}{l}\text { Not Very } \\
\text { True }\end{array}$ & $\begin{array}{l}\text { Aware of the } \\
\text { environment } \\
(N=1,159)\end{array}$ & $\begin{array}{l}\text { Lack of } \\
\text { interest } \\
(N=908)\end{array}$ \\
\hline
\end{tabular}

Figure 2. Interest in Technology and Awareness of the Environment-Four Types

cally minded and uses it only if he has no other choice. He enjoys "somebody else doing the driving" (Anonymous, personal communication, spring 2002). He moved houses to be closer to his school and to avoid the daily drive there. A holiday, for him, begins the moment he "gets on a train." He appreciates the functional provision of public transportation.

Thus, we can see that there are different types of mobility depending on people's attitudes toward technology.

\section{Interest in Technology and \\ Environmental Awareness}

To show the connection between environmental awareness and a technological orientation, two variable complexes will be divided into four groups by doing a cluster analysis. ${ }^{13}$ To the greatest possible extent, the statistically determined groups correspond to the types of environments that have been developed in a qualitative study concerning the environmental knowledge of young people (see Lappe, Tully, \& Wahler, 2000, pp. 173-203 and Table 7).

Those consistently aware of the environment in our sample survey compose about one quarter of the interviewees. Their attitudes toward technology are rather skeptical, and the environment plays an important role in their behaviors. According to Lappe et al. (2000),

Young people are involved who clearly convey their interest in environmental issues, whose cognitive and emotional assimilation of environmental problems is very intense, and who give expression to their personal concern for the environment. . . . The crucial factor is that these young people strongly emphasize their own activities, skills and control competency with regard to ecological initiatives. (pp. 173-203)

The environmentally aware people are mainly women, more mature youths, and adolescents with a higher education.

There is nothing in Lappe et al. (2000) that corresponds to young people who display a consistent interest in technology. Young people who express exclusively technology-oriented opinions without any consideration for ecological aspects can be found (see Hunecke, Tully, and Bäumer, 2002) almost as frequently as those who are consistently aware of the environment. Of technology-oriented people, $80 \%$ are men, $43 \%$ are quite young, and $61.5 \%$ have an average or lower education. There are hardly any differences worth mentioning with regard to origins and professional status, with the one exception being that close ties to technology can be found more frequently among vocational trainees than among working people and college students.

In addition, there are two mixed types: those who delegate and those who lack interest.

We have classified those young people as "consistently delegating" who make somewhat of a show of their environmental interest, but whose awareness of environmental destruction must be described as rather limited. ... The decisive factor for classifying interviewees in this category was, however, that they delegate responsibility for taking ecological action either to their parents and siblings or to public institutions ...., thus externalizing that responsibility. (Lappe et al., 2000, p. 176)

In our case, we cannot say that the environment plays no role whatsoever in the behavior of people who delegate. It is more important to see that they believe technological progress can solve today's environmental problems. They delegate some of the responsibility to modern technologies and other institutions, such as politics and the economy, responsible for environmental protection. We shall not deal any further here with the group of those who lack interest.

\section{References to the Working World}

Technology II can be found not only in young people's leisure-time environments but also at school and 
Table 5. Development of Training Vacancies in New Media and IT Professions in 2000 and 2001

\begin{tabular}{|c|c|c|c|c|c|c|}
\hline \multirow[b]{3}{*}{ Job Area } & \multicolumn{2}{|r|}{ Year 2000} & \multicolumn{2}{|r|}{ Year 2001} & \multirow{2}{*}{\multicolumn{2}{|c|}{$\begin{array}{l}\text { Changes Compared } \\
\text { With Preceding Year }\end{array}$}} \\
\hline & & $\%$ of All Jobs Requiring & & $\%$ of All Jobs Requiring & & \\
\hline & Total & Vocational Training & Total & Vocational Training & Total & $\%$ \\
\hline The media & 7.530 & 1.2 & 8.107 & 1.3 & 577 & 7.7 \\
\hline IT field & 18.024 & 2.9 & 20.447 & 3.3 & 2.423 & 13.4 \\
\hline All 11 new jobs together & 25.554 & 4.1 & 28.554 & 4.6 & 3.000 & 11.7 \\
\hline All jobs together & 621.693 & 100.0 & 613.852 & 100.0 & -7.842 & -1.3 \\
\hline
\end{tabular}

Source: The author's calculations are based on the Report on Vocational Training (Note 28). (Bundesministerium für Bildung und Forschung, 2002, p. 297f).

in vocational training. When new technology in the working world is at issue, we have at least three priority areas: changes in the content of training, the company's work processes, and a reorganization of client relationships. When the time is ripe for the transition from school to a job, the first area becomes especially important. Questions such as what profession a person should train for, whether this profession has a future, and what kinds of technical knowledge are required beforehand arise. As for changes in professions and their training contents, technology-induced revisions can be found at two levels: (a) A basic knowledge of information technology with different complementary studies is compulsory for all jobs and should become part of all training programs in vocational schools and in companies and (b) new job profiles are created and expected to take into account the special needs of a technology-oriented society. In the last 5 years, 11 new job profiles have been implemented by the government. Media jobs and jobs in the information technology field are concerned. In concrete terms, we are talking about, for instance, the media creator for digital and print media, the specialized computer scientist, or the commercial manager for computer sales.

As Table 5 shows, job offers in these fields have increased strongly within a year, in contrast to the overall German trend in the job market (see Bundesministerium für Bildung und Forschung, 2002). Already, every 25 th vocational training takes place within this newly created sector. There are more than 300 jobs that legally require vocational training. At the same time, the strong demand for these new professions among young people is quite obvious.

Computers and the Internet have created new job profiles. Just as lastingly, they have changed and continue to change the working world and the relations between companies and clients. First of all, computers ensured that, in companies, the multiple recordings of data, texts, and other documents were no longer necessary. In a next step, intranets and the Internet facilitated the archiving of documents on a main server that can be accessed from all work stations. To that extent, working with files and with documents has been simplified and rationalized, and previously discontinuous administrative processes were abolished. Nowadays, people transporting files within administrations are the exception. Similarly, client relations have been reorganized. Already, clients can present their cases in digital form. In terms of system theory, organizations use computers and the Internet to extend the boundaries of their systems and to include other subsystems to enhance performance. A new situation has evolved: Responsibility has been delegated back to the individual. If you want to travel by train, you might want to use the Internet to order your ticket and print it out yourself. If you want to pay your phone bill, you should download it first. The service society seems to be coming to an end to the extent that self-service possibilities increase. The individual's time budget is burdened because more and more time must be invested in activities that, previously, were taken care of by service providers. At the same time, compatibility is a must because people need to have the latest technology at their disposal.

\section{Conclusion}

Learning to cope with the natural and the social environment has changed permanently with the appearance of modern technical aids. To demonstrate this clearly, the distinction was made between Technology I, the industrial type, and Technology II, the everyday type. The main feature of Technology II is that it can be used in many different ways; its applications are not predetermined. Correspondingly, a meaningful individual choice can be made among a number 
of options and put into context. What matters here is not simplification and rationalization but rather convenience, comfort, and joy in the experiences of everyday life. Young people grow up in the world of Technology II. They are interested in it, they encounter it in various social contexts, they have a wide range of devices at their disposal, and they use them to produce new meanings and lifestyles. This situation is quite challenging for academic research on young peopletraditional methods are proving to be insufficient. Research is overdue that examines the changes in young people's everyday lives and the social consequences of those changes. In particular, intercultural comparisons must deal with the following questions: Which are the truly relevant technical objects? How are they used? What is the role of specific constellations (e.g., in peer groups)? Who teaches girls and who teaches boys how to deal with devices? How much time and money do young people really invest in new technology? Do typical leisure-time activities that young people used to be involved in, such as being together in groups, doing sports, or taking on political commitments, suffer from the way new technology penetrates young people's everyday lives? What opportunities and risks are involved? What relationship patterns to older generations can be found? All of these questions and many more indicate that a great deal of research is required. An information technology society, to merit that name, must examine the foundations it is built on and in particular the possibilities of negotiating its impact in terms of socialization.

\section{Notes}

1. Technology I and Technology II coexist side by side, and we cannot speak of a logical development from one to the other (see Tully, 2003).

2. According to Degele (2002),

Hybrids such as the hole in the ozone layer, the AIDS virus, the BSE pathogen, or the vacuum produced by a vacuum pump are located between nature and society, and that applies to technology as well. For Latour, the modern paradox lies in the fact that nature is becoming increasingly socialized, whereas social developments are becoming increasingly natural and disordered. (p. 136)

3. The term gadgets stands for all the little, technical helpers in everyday life.

4. According to Sackmann and Weymann (1994),

In groups sharing generation-specific experiences, experiences acquire shared meanings. As collective ideas, they give objects and actions a meaning that transcends any par- ticular situation. Meaning ... depends on generation-specific concepts and experiences. (p. 17)

5. For a summary of the project, see Hunecke, Tully, \& Bäumer, 2002.

6. Generally, young people's attitudes are not negative. Hostility towards technology is not and was never an issue among young people (see Wahler \& Tully, 1991).

7. Exemplary items are "For me, driving means freedom" and "I find walking is a bore."

8. All the differences of attitudes mentioned are significant at least at the $5 \%$ level.

9. This is not an effect of age because the distribution of age groups is about the same; there is even a tendency for technology fans to be a bit younger.

10. See 18-year-old Andreas's quote under Technology as an Object of Social Differentiation.

11. A cluster-center analysis was done. The variable, "If you understand technology, you have more fun driving" was considered ( 1 = not true; $5=$ very true), as was the variable, "Cars are utility articles only" ( $1=$ not true; $5=$ very true $)$. Both variables were $\mathrm{z}$-standardized and corresponding to theoretical predictions, we aimed at a four-cluster solution.

12. Only $18 \%$ of interviewees can be assigned to the interested and not interested groups. For the not-interested people, technology plays no role whatsoever in their daily lives. Interested people, however, have controlling as well as utility-oriented access to technology. Hence, the two dimensions do not exist independently of each other.

13. A cluster-center analysis was done. The variable, "I am interested in technology" was considered ( $1=$ not true; $5=$ very true $)$, as was a scale for environment orientation (consisting of 5 items with 0.67 reliability). For example, for "Environmental protection plays an important role in my behavior," $1=$ is absolutely untrue and $6=$ is entirely true. Both variables were $z$-standardized and according to theoretical predictions and practical considerations, we aimed at a 4-cluster-solution.

\section{References}

Degele, N. (2002). Einführung in die Techniksoziologie [An introduction to technological sociology]. Munich, Germany: Wilhelm Fink.

Bundesministerium für Bildung und Forschung [Federal Ministry for Education and Research] (2002). Berufsbildungsbericht 2002 [Report on vocational training]. Bonn, Germany: Moser $\mathrm{GmbH}$.

Fritzsche, Y. (2000). Modernes Leben: Gewandelt, vernetzt und verkabelt [Modern life: Transformed, networked, linked up to cables]. In Jugend 2000. 13. Shell-Jugendstudie [13th Shell Youth Study] (pp. 181-220). Opladen, Germany: Deutsche Shell.

Deutsche Shell (Ed.). (2002). Jugend 2002. 14. Shell Jugendstudie [Youth 2002: 14th Shell Youth Study]. Frankfurt, Germany: Deutsche Shell.

Höflich, J. R. (2001). Das Handy als "persönliches Medium”. Zur Aneignung des Short Message Service (SMS) durch Jugendliche [Cell phones as "personal media": How young people use the Short Message Service (SMS)]. Kommunikation@ Gesellschaft, 2, 1-19. 
Hunecke, M., Tully, C. J., \& Bäumer, D. (2002). Mobilität von Jugendlichen. [Young people's mobility]. Opladen, Germany: Leske + Budrich

Lappe, L., Tully, C. J., \& Wahler, P. (2000). Das Umweltbewusstsein von Jugendlichen [The ecological awareness of adolescents]. Munich, Germany: Verlag Deutsches Jugendinstitut.

Latour, B. (1995). Wir sind nie modern gewesen. Versuch einer symmetrischen Anthropologie [We have never been modern: Attempting the design of a symmetrical anthropology]. Berlin, Germany: Fischer.

Luhmann, N. (1992). Beobachtungen der Moderne [Observing modernity]. Opladen, Germany: Westdeutscher Verlag.

McLuhan, M. (1968). Die magischen Kanäle. [Understanding media]. Düsseldorf, Germany: Econ.

JIM-Studie. (1999). Jugend, Information, (Multi-) Media 1998 [Youth, Information (Multi-)Media 1998]. Baden-Baden, Germany: Medienpädagogischer Forschungsverbund Süudwest.

JIM-Studie. (2002). Jugend, Information, (Multi-) Media 2001 [Youth, Information, (Multi-)Media 2001]. Baden-Baden, Germany: Medienpädagogischer Forschungsverbund Süudwest.

KIM-Studie. (2001). Kinder und Medien, Computer und Internet 2000 [Children and computers, the media and the Internet, 2000]. Baden-Baden, Germany: Medienpädagogischer Forschungsverbund Süudwest.

Popitz, H. (1995). Der Aufbruch zur artifiziellen Gesellschaft [The emergence of an artificial society]. Tübingen, Germany: Mohr.

Sackmann, R., \& Weymann, A. (1994). Die Technisierung des Alltags. Generationen und technische Innovationen [The tech- nological infiltration of everyday life: Generations and technological innovations]. Frankfurt, Germany: Campus.

Sombart, W. (1987). Der moderne Kapitalismus [Modern capitalism]. Munich, Germany: Leipzig. (Original work published 1927)

Tully, C. J. (1998). Rot, cool und was unter der Haube. Jugendliche und ihr Verhältnis zu Auto und Umwelt [Red, cool and something under the hood: Young people and their relationship to cars and the environment]. Munich, Germany: Olzog.

Tully, C. J. (2000). Jugendliche Netzkompetenz: Just do itSurfen im Cyberspace als informelle Kontextualisierung [Young people's network competency: Just do it-Surfing in cyberspace as informal contextualization]. In The educational value of the Internet (pp. 189-216). Opladen, Germany: Leske + Budrich.

Tully, C. J. (2003). Mensch-Maschine-Megabyte [Man-machinemegabyte: Technology in everyday life]. Opladen, Germany: Leske + Budrich

Wahler, P., \& Tully, C. J. (1991). Young peoples attitudes to technology. European Journal of Education, 26(3), 261-272.

Weber, M. (1956). Wirtschaft und Gesellschaft [Economy and society]. Tübingen, Germany: Mohr.

Claus J. Tully has been an academic consultant at the German Youth Institute since 1980. He is also a lecturer in sociology at the Technical University of Munich in Germany and at the Free University of Bozen in Italy. His research interests include youth, technology, education, environment, mobility, and the informalization of social relationships. 


\section{Request Permission or Order Reprints Instantly}

Interested in copying, sharing, or the repurposing of this article? U.S. copyright law, in most cases, directs you to first get permission from the article's rightsholder before using their content.

To lawfully obtain permission to reuse, or to order reprints of this article quickly and efficiently, click on the "Request Permission/ Order Reprints" link below and follow the instructions. For information on Fair Use limitations of U.S. copyright law, please visit $\underline{\text { Stamford University Libraries, }}$, or for guidelines on Fair Use in the Classroom, please refer to The Association of American Publishers' (AAP).

All information and materials related to SAGE Publications are protected by the copyright laws of the United States and other countries. SAGE Publications and the SAGE logo are registered trademarks of SAGE Publications. Copyright (C) 2003, Sage Publications, all rights reserved. Mention of other publishers, titles or services may be registered trademarks of their respective companies. Please refer to our user help pages for more details: http://www.sagepub.com/cc/faq/SageFAQ.htm

\section{Request Permissions / Order Reprints}

